\title{
Cinema and History in the Americas
}

Cinéma et histoire dans les Amériques

Cine e historia en las Américas

\section{Ignacio Del Valle Dávila and Eduardo Morettin}

Translator. Michael Hinchliffe

\section{(2) OpenEdition}

1 Journals

\section{Electronic version}

URL: https://journals.openedition.org/ideas/3103

DOI: 10.4000/ideas.3103

ISSN: 1950-5701

This article is a translation of:

Cinéma et histoire dans les Amériques - URL : https://journals.openedition.org/ideas/1503 [

Other translation(s):

Cine e historia en las Américas - URL : https://journals.openedition.org/ideas/3113 [es]

Cinema e história nas Américas - URL : https://journals.openedition.org/ideas/3144 [pt]

\section{Publisher}

Institut des Amériques

\section{Electronic reference}

Ignacio Del Valle Dávila and Eduardo Morettin, "Cinema and History in the Americas", IdeAs [Online], 7| 2016, Online since 26 July 2018, connection on 19 October 2022. URL: http:// journals.openedition.org/ideas/3103 ; DOI: https://doi.org/10.4000/ideas.3103

This text was automatically generated on 19 October 2022

\section{(c) $)(9)$}

Creative Commons - Attribution-NonCommercial-NoDerivatives 4.0 International - CC BY-NC-ND 4.0 https://creativecommons.org/licenses/by-nc-nd/4.0/ 


\title{
Cinema and History in the Americas
}

\author{
Cinéma et histoire dans les Amériques \\ Cine e historia en las Américas
}

Ignacio Del Valle Dávila and Eduardo Morettin

Translation : Michael Hinchliffe

1 The cinema is one of the foremost artistic and cultural media of the $20^{\text {th }}$ and $21^{\text {st }}$ centuries. It is also a powerful tool for mass communication. These factors have made it a primary source of great interest in the study of developments both in the political sphere and the collective imagination of given communities at specific historical periods. Hence the considerable number of researchers who have paid close attention to the relationship between cinema and history.

One aim of this "Cinema and History in the Americas" dossier is to reach a better understanding of the role played by the cinema in the representation of the historical past of various countries throughout the American continent. But at the same time, our purpose is also to put forward various practical propositions as to the ways in which the cinema may be used as source material in historical study. As a result, articles include studies looking at the beginnings of cinema or examining its more recent trends: silent films, the shift from visual to audiovisual language, the rise of melodrama and the historical film, the cinema d'auteur of the sixties, the political cinema of the sixties and seventies, and the autobiopics of the last twenty years.

No exhaustive account of the principal theoretical approaches to the cinema studied from a historical perspective is possible within the limits of the pages that follow here. We shall be confining ourselves to certain inflections of developments in the field. Overall it is safe to say that it took both documentary and fiction films decades to establish their legitimacy as a source for history, in spite of both their strong public penetration as mass entertainment - in the case of fiction especially - and their double status as artistic expression and industry. The methodological principles governing the use of cinema as source material for the historian were not systematized until the seventies, with the work of Marc Ferro, published in book form in 1977 as Cinéma et histoire (Cinema and History). Ferro contends that the study of the moving 
image may serve as a launching pad for what he calls a "counter-analysis of society", whereby areas of latent reality are laid open, "invisible zones of the society's past, revealing that society's processes of self-censorship and lapsus" (Ferro M., 2009:27). Notwithstanding the extensive discussion and criticism to which Ferro's theory has given rise during the last thirty years, his defense of the value of the moving image as an "historical document" and an "historical agent" within the society that produces and consumes it is still fully relevant for research into the relations between the cinema and history (Ferro M., 2009: 17).

To the field were soon added the studies produced by Pierre Sorlin: Sociologie du cinéma, (Sorlin P., 1977), and The Film in History. Restaging the Past (Sorlin P., 1980). Sorlin takes particular interest in the relationship between historical fiction in the cinema and history as an academic discipline and has attempted to show how representations of the past on the screen allow contemporary political topics to show through. However, as he himself has recognized, his 1980s interest in semiotics as a method for film analysis has lost much of its relevance today.

5 In the final decade of the $20^{\text {th }}$ and the first two of the $21^{\text {st }}$ century, work bringing together cinema and history has become more extensive and diverse. Beyond revisions in methodology, a number of studies have concentrated on the analysis of a particular film or a specific context and have been able to verify the validity of general principles. Michèle Lagny, working in the French context, has looked at the development of a methodology which, without eschewing the analysis of the film's text, holds that, over and above the determination of the political and economic conditions of production, an indispensable aspect of its interpretation must be its insertion into cultural context and cinematographic tradition (Lagny M., 2009). In a very different perspective, Pierre Beylot and Raphaëlle Moine, noting the proliferation of "period films", have been interested since the 1980s in the links between historical fiction films and the notion of historic and cultural heritage (Beylot P. and R. Moine, 2009). Sylvie Lindeperg has developed the concept of micro-history in motion to explain her approach to Alain Resnais' Night and Fog (Nuit et brouillard, Alain Resnais, 1955). Her work on the film calls equally on an analysis of cinematographic forms and a highly detailed study of the context of its production and distribution (Lindeperg S., 2007: 8). For Antoine De Baecque, the key concept is that of "camera as history", whereby he seeks to show that the cinema can be seen as a form of history by virtue of its ability to represent the past, to become itself an archive of the past and, through the process of film editing, to arrive at new forms of reflection on a past reconstructed or preserved on film (De Baecque A., 2008: 13).

6 In the US, the work of Robert Rosenstone has made a considerable mark. For him, historical films including fiction, together with the productions of other audiovisual media, mold our consciousness of history. Rosenstone's primary purpose is an enquiry into the ways in which films actually create an historical world (Rosenstone P., 2010).This attempt to apprehend how the cinema gives rise to knowledge of the past leads Rosenstone to juxtapose on the same plane the activity of the film-maker and the historian, despite the fact that the former's work has a mode of interaction with the past different from the latter's written word (Rosenstone R., 2010: 22). Rosenstone's argument is that the cinema and written history constitute convention-governed narratives within both of which may be found elements either imaginary or unreal. In 
this way, he subsumes academic and spectacle-oriented history into a single blurred category based on narrative.

7 Another factor to notice is the renewal in the field of cinema history. The Brighton Congress of the International Federation of Film Archives in 1978 highlighted the proximity between film and questions raised by cultural history and this led to methodological propositions for film analysis which included the historical dimension. In the words of Tom Gunning, a participant in the Congress:

Although the methods of film analysis as signifying systems differ from those of films as market products, they are not mutually exclusive nor are they independent in the last resort. [...]. We need to develop methods of analyzing films as such which include a historical dimension [...] it is high time to conduct a diachronic comparison of films within history (Gunning T., 1990: 86).

Rosenstone, Ferro and Sorlin are the main authors with whom Latin American research has been able to enter into dialogue. This is partly owing to the fact that some of their work has been translated into Portuguese and Spanish. The field has developed particularly in Brazil where, since the mid-nineties, there has been an abundance of scientific literature ${ }^{1}$. Particular mention may be made of the following: História e cinema (Capelato M. H., Morettin, E., Napolitano M. et al., 2007); Cinematógrafo: um olhar sobre a história (Nóvoa J., Biscouto Fressato S. and Feigelson K., 2009); História e Audiovisual, a special issue of the journal Estudos Históricos (Kornis M., 2012); the book História e documentário (Morettin E., Napolitano M. and Kornis M., 2012); the dossier As imagens no tempo e os tempos da imagem in the journal Histórica, Questões \& Debates (Bastos Kern M. L. et Kaminski R., 2014). Also worth mentioning are various monographies such as: Canibalismo dos fracos (Freire Ramos A., 2002), relative to the film Os Inconfidentes (Joaquim Pedro de Andrade, 1972), or Humberto Mauro, Cinema, História (Morettin E., 2013), together with a considerable number of papers, day conferences, congresses, seminars and research projects.

9 Any film is in dialogue with the society and the period in which it was made. It incorporates and brings into play the imaginations and ideologies of a society in conflict even as it has the potential to inflect them, by functioning as an historical agency. We shall therefore be paying close attention to the way in which the films under study contribute both to the construction of socially shared image systems and to the defense of political discourse or project. Prerequisite to using the cinema as source material for history is the necessity of taking into account a film's artistic specificity as well as the characteristics inherent in audiovisual language. Failure to do so would be to risk analyzing films with a methodological array inherited from the written text, inadequate to the purpose of presenting the cinema as a document of and for its time. It is, therefore, very much a question of acknowledging the specific nature of cinematographic study. And a corollary of this is the need to stress the importance of film analysis as a tool both for the study of cinematographic documents and for the establishment of programmatic research guidelines.

10 The papers presented here cover three geographical zones -South America, the Caribbean and North America- and four linguistic spaces - Spanish, Portuguese, English, French. We have opted for the study of nation-based cases in order to obviate the risk of a generalist approach which would lack depth. However, when it came to concrete cinematographic experiences concerned with exile and migration, it was 
obviously necessary to forego national limits and adopt the transnational treatment the topic required.

11 We begin with Brazil and the articles by Ismail Xavier, Eduardo Morettin and Fernando Seliprandy. Xavier looks at the relationship between historical allegory and commitment in the films of Glauber Rocha, active between the years 1959 and 1980. Morettin analyzes the connections between cinematographic and historical discourse in the representation of the colonizing power produced by Humberto Mauro at a time when the government of Getúlio Vargas (1930-1945) was in search of symbolic legitimization. Seliprandy studies convergences and divergences in the case of two documentaries about the guerilla fighter Carlos Marighella: Marighella: retrato falado do guerrilheiro (Silvio Tendler, 2001) and Marighella (Isa Grinspum Ferraz, 2012).

Two articles on Argentinean cinema deal with 1970s and 1980s fiction. In the first, Ignacio Del Valle Dávila studies the relationship between historical cinema and the ideological project behind the so-called "Argentine Revolution" dictatorship (1966-1973) as evinced in the film El Santo de la Espada (Leopoldo Torre-Nilsson, 1970) about José de San Martín (1778-1850), the hero of the country's independence. In the second, Ana Laura Lusnich deals with the pre-eminence of allegory and metaphor in films made during the last Argentinean dictatorship (1976-1983) and in the early postdictatorial period (1983-1989) as a reflection on the state-driven terror and social control characteristic of that period. Lusnich's study concentrates on two feature films: Los Medios (Alejandro Doria, 1980) and Hay unos Tipos Abajo (Rafael Filipelli, Emilio Alfaro, 1985).

Mariana Villaça tackles the relationship between the cultural policy of the Cuban government and the influential Insituto Cubano del Arte e Industría Cinematográfica (ICAIC), bringing out as she does so the internal conflicts between the Institute's direction and several critical filmmakers at two particularly tense moments in Cuba's cultural landscape, 1968 and the early 1970s. Two films, Coffea Arábiga (Nicolás Guillén Landrián, 1968) and El Otro Francisco (Sergio Giral, 1973) provide her with cogent means to analyze these relationships.

14 The articles by Anne-Marie Paquet-Deyris, Sergio Alpendre and Vincent Souladié are concerned with different moments of US filmmaking. Paquet-Deyris gives a study of the cinematographic representation of President Abraham Lincoln in three films spanning the 1930s: Abraham Lincoln (D.W. Griffith, 1930), Young Mr Lincoln [French title: Vers sa destinée] (John Ford, 1939) and Abe Lincoln in Illinois (John Cromwell, 1940). The other two papers concern Hollywood films and take a look at revisions of the so-called American dream in moments of crisis. Alpendre studies Rocky (John G. Avilsden, 1976) and Saturday Night Fever (John Badham, 1977), films he considers as metaphors of a shock moment of capitalism when faced with the first oil crisis (1973). Souladié provides a critical analysis of the relationships between super-hero images in superhero films made subsequent to nine eleven and the twin tower attacks.

Study of the relationships between cinema and history in North America closes with the analysis of a francophone documentary from Quebec. Henri Gervaiseau examines Le règne du jour (Pierre Perrault, 1967) with a view to looking at how displacement from one social and geographical space to another far away draws out a sentiment of territorial belonging. The collection itself closes with an article on the subject of cinematographic experiences linked to migration and political exile, with a focus on transnational circulation and exchange. Jennifer Cazeneuve tackles the experiences of 
migration and exile with the study of two "journal-films": Reminiscences of a Journey to Lithuania (Jonas Mekas, 1973) and Diary (David Perlov, 1973-1983).

This collection as a whole offers a varied and complex view of the relationship between the cinema and history on the American continent based on specific cases which include an analysis both of national context and transnational circulation. We would stress that the historical perspective giving these studies direction helps to bring about a productive commingling of researchers from different horizons. That we have here papers from specialists in the history of film, in cinematographic analysis, in communication and in aesthetics is a clear indication of the fact.

The reader will hardly fail to notice that the approach taken and the themes evoked in different pieces enter into dialogue. Ismail Xavier and Ana Laura Lusnich both stress the importance of allegory in film; founding narrative is a theme with which Eduardo Morettin, Ignacio Del Valle Dávila and Anne-Marie Paquet-Deyris are all concerned; the film as essay is important for Jennifer Cazeneuve and Henri Gervaiseau, as is the hagiographic portrait for Anne-Marie Paquet-Deyris, Ignacio Del Valle Dávila and Fernando Seliprandy; the linkage between film and revolutionary project appears in the pieces by Ismail Xavier and Mariana Villaça.

Over and against the multiplicity of questions involved, all the articles collected here share the same characteristic, the central position given to film analysis for an understanding of the historical phenomena within which the cinematographic works studied are inscribed. We did not consider at the outset that limiting the possible number of thematic approaches would be a valid proposition. However it now seems possible to pick out general tendencies. All these contributions deal, directly or indirectly, with the relationship between art and politics at different periods and in different forms. In this perspective, it is of interest to note that the pieces on Latin America bring out both the high point and the crisis of the cinema engaged in revolutionary projects, while also stressing the varying degrees of tension between cinematographic production and authoritative government. Where the pieces on the US are concerned, the main focus falls rather on the relationship between the expansion of the film market, which has made possible increasingly spectacular productions since the beginning of the $20^{\text {th }}$ century, and the installation or revision of melodramatic narratives about the deeds and ambitions of individual heroes. These narratives are predicated upon an image system promoting competition, the struggle for social ascension and success, a basic characteristic of North American society.

19 This project originated in late 2013 when a first proposition was tendered to IdeAs, the initiative for which came from the research group "História e Audiovisual: circularidades e formas de communicação" (History and Audiovisual Studies: circulation and forms of communication), coordinated by professors Eduardo Morettin and Marcos Napolitano at São Paulo University. From the outset, the aim was to call on researchers from other academic institutions and thereby promote international exchange. But apart from the institutional diversity here, national origins are highly varied (Brazilian, French, Argentinean, Franco-Brazilian, Franco-American, HispanoChilean), a fact which bears witness to the increasing internationalization of academic research ${ }^{2}$. In the last analysis, the plurality evinced in this collection is also proof of the consolidation of a field of study bringing together thinking on the cinema and social science. 


\section{BIBLIOGRAPHY}

Bastos Kern, Maria Lúcia et Kaminski, Rosane (org.), As imagens no tempo e os tempos da imagem, História Questões \& Debates, nº 61, 2014.

Beylot, Pierre et Moine, Raphaëlle (dir.), Fictions patrimoniales, sur grand et petit écran, Bordeaux, PUB, 2009.

Capelato, Maria Helena ; Morettin, Eduardo ; Napolitano, Marcos ; Saliba, Elias Thomé (org.), História e cinema, São Paulo, Alameda, 2007.

De Baecque, Antoine et Chevalier, Philippe, Dictionnaire de la pensée du cinéma, Paris, Puf, 2012.

De Baecque, Antoine, L'histoire-caméra, Paris, Gallimard, 2008.

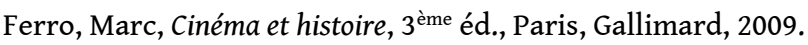

Freire Ramos, Alcides, Canibalismo dos fracos, Bauru, EDUSC, 2002.

Gunning, Tom, «Non-continuity, Continuity, Discontinuity. A Theory of Genres in Early Films», in Thomas Elsaesser (éd.), Space, Frame, Narrative, Londres, BFI Publishing, 1990.

«História e Audiovisual: circularidades e formas de comunicação» : http:// historiaeaudiovisual.weebly.com/teses-e-dissertaccedilotildees.html, page consultée le 26 mars 2016.

Kornis, Mônica Almeida (org.), História e Audiovisual, Estudos Históricos, vol. 26, n 51, 2013, http:// lisa.revues.org/index846.html, page consultée le 31 mars 2016.

Lagny, Michèle, «O cinema como fonte da história», in Jorge Nóvoa, Soleni Fressato et Kristian Feigelson, (dir.), Cinematógrafo: um olhar sobre a história, Salvador, EDUFBA; São Paulo, Edunesp, 2009, p. 99-132.

Lindeperg, Sylvie, «Nuit et brouillard» un film dans l'histoire, Paris, Odile Jacob, 2007.

Morettin, Eduardo ; Napolitano, Marcos, Kornis, Mônica Almeida (org.), História e documentário, Rio de Janeiro, Editora FGV, 2012.

Morettin, Eduardo, Humberto Mauro, Cinema, História, São Paulo, Alameda, 2013.

Nóvoa, Jorge ; Fressato, Soleni ; Feigelson, Kristian (org.), Cinematógrafo: um olhar sobre a história, Salvador, EDUFBA; São Paulo, Edunesp, 2009.

Rosenstone, Robert, A história nos filmes, os filmes na história, traduit de l'anglais (États-Unis) par Marcello Lino, [éd. orig. History on Film/Film on History, Harlow, Pearson Education] São Paulo, Paz e Terra, 2010 [2006].

Sorlin, Pierre, Sociologie du cinéma : ouverture pour l'histoire de demain, Paris, Aubier Montaigne, 1977.

Sorlin, Pierre, The film in history : restaging the past, Oxford, Basil Blackwell, 1980. 


\section{NOTES}

1. A list of these works is available online on the site of the research group "Histoire et Audiovisuel : circularités et formes de communication":http://historiaeaudiovisual.weebly.com/ teses-e-dissertaccedilotildees.html. Page consulted 26 March 2016.

2. The academic career of professor Ismail Xavier, whose contribution opens the collection, may be cited as a case in point. He is one the main international autorities on the work of Glauber Rocha and on allegory in Latin American cinema and his work has been extensively translated in Europe, the United States and in Latin America. His work has given rise to an entry concerning him in the Dictionnaire de la pensée du cinéma [Dictiionary of Cinematographic Thought] (De Bacque A., and Chevalier P., 2012).

\section{AUTHORS}

\section{IGNACIO DEL VALLE DÁVILA}

Ignacio Del Valle Dávila is Spanish and Chilean in origin. He won a doctorate in film studies (University of Toulouse - Jean Jaurès) and carried out postdoctoral studies in history at the University of São Paulo. He at present teaches postgraduate students at the Arts Institute of the University of Campinas (Unicamp) while continuing research into Latin American cinema on a post-doctoral CAPES grant. He is the author of two books: Cámaras en trance : el nuevo cine latinoamericano, un proyecto cinematográfico subcontinental (Santiago du Chili, Cuarto Propio, 2014) and Le nouveau cinéma latino-américain (1960-1974) (Rennes, PUR, 2015). He is a member of the research group CNPq "História e Audiovisual: circularidades e formas de comunicação" and of the editoral board of the journal Cinémas d'Amérique latine.

\section{EDUARDO MORETTIN}

Eduardo Morettin is professor of Audiovisual History at the School of Communications and Arts, São Paulo University. He is the author of "Humberto Mauro, Cinema, História" and one of the organisers of "História e Cinema: dimensões históricos do audiovisual" ( $2^{\text {nd }}$ ed, SP, Alameda Editorial, 2011), "História e Documentário" (RJ, FGV, 2012) and "Visualidades Hoje" (Salvador, Edufba, 2013). He has been a member of the Board of the Brazilian Cinema Library since 2007 and is one of the leading members of the group "História e Audiovisual: circularidades e formas de comunicação" (website http://historiaeaudiovisual.weebly.com). He is a CNPq researcher (Level 2 prize for academic output), having carried out a postdoctoral fellowship at the University of Paris 1 (2012). 